\title{
Witold Kulesza
}

Uniwersytet Łódzki

wkulesza@wpia.uni.lodz.pl

ORCID: https://orcid.org/0000-0003-2593-6801

\section{Polacy wpisani na volkslistę a obowiązek służby w Wehrmachcie w świetle wyroków Sądu Specjalnego w Toruniu*}

\section{Sytuacja Polaków na Pomorzu w latach 1939-1945}

Według raportu $z$ końca 1943 r. napisanego przez Alberta Forstera, gauleitera Okręgu Rzeszy Gdańsk - Prusy Zachodnie (Reichsgau Danzig - Westpreussen), utworzonego z ziem północnej Polski wcie-

* Sondergericht in Thorn działał od dnia 16 stycznia 1942 r. do dnia 31 grudnia 1943 r. (K. Przybyszewski, Z działalności hitlerowskiego Sądu Specjalnego (Sondergericht) $w$ Toruniu 1942-1943, „Rocznik Toruński”, T. 2, Torun 1967). Akta 20 spraw, w których sąd ten wydał wyroki śmierci, znajdują się w Archiwum Federalnym (Bundesarchiv) w Berlinie, w dziale dokumentów Ministra Sprawiedliwości Rzeszy (Reichsminister der Justiz), uprawnionego z mocy upoważnienia Adolfa Hitlera do decydowania o wykonaniu tych wyroków (H. Schlüter, „...für die Menschlichkeit im Strafmaß bekannt...”. Das Sondergericht Litzmannstadt und sein Vorsitzender Richter, „Juristische Zeitgeschichte NRW“, Band 14, Recklinghausen 2007, s. 86). Kopie omawianych poniżej dokumentów pochodzą $z$ tego archiwum. 
lonych do III Rzeszy dekretem Adolfa Hitlera z dnia 8 października 1939 r., na niemiecką listę narodowościową w jej części III wpisano ponad 700 tys. osób uznanych za pochodzących z niemczyzny, „które wprawdzie w pewnym stopniu uległy polonizacji, ale nie występowały przeciwko Niemcom”, a także małżeństwa mieszane, w których „dominowała strona niemiecka” 2 . Z listy tej powołano do służby w Wehrmachcie ponad 70 tys. mężczyzn, z których 1700 poległo ${ }^{3}$.

Po tym, jak jesienią 1939 r. przeprowadzono ludobójczą Intelligenzaktion, mającą na celu pozbawienie narodu polskiego warstwy przywódczej, która na Pomorzu pochłonęła ponad 60 tys. ofiar, i zimą, w strasznych, powodujących śmierć tysięcy ludzi warunkach, rozpoczęto masowe deportacje do Generalnego Gubernatorstwa, zamysłem Forstera stało się zniemczenie jak największej liczby pozostałych pod jego władzą mieszkańców ${ }^{4}$. Jego koncepcja germanizacji zakładała osiągnięcie konkretnych korzyści, polegających na pozyskiwaniu żołnierzy i robotników, którzy wpisani na niemiecką listę narodowościową będą wydajniejsi aniżeli robotnicy przymusowi, ponieważ narzucona została im zależność zobowiązująca do akceptacji warunków stworzonych przez władze Rzeszy. Forsterowi nie chodziło zatem o faktyczny „związek krwi”, lecz o wywołanie poczucia przynależności do niemczyzny poprzez wciągnięcie na volkslistę dużej części Polaków zamieszkałych w nowych granicach Niemiec. Gauleiter miał przy tym ambicję możliwie szybkiego zameldowania Hitlerowi, że jego okręg został już oczyszczony z Polaków, a drogą do osiągnięcia tego stanu było wykazanie w raportach, że mieszkańcy rządzonego przezeń kraju to Niemcy i zapisani na listę narodowościową Volksdeutsche, inni zaś zostali już wysiedleni. Reichsführer SS Heinrich Himmler, który forsował program fizycznej likwidacji lub wysiedlenia wszystkich obcoplemiennych $z$ Niemiec w ich nowych granicach, potępiał zaliczanie do kategorii Volksdeutschy tych

2 D. Schenk, Albert Forster gdański namiestnik Hitlera, Gdańsk 2002, s. 297.

${ }^{3}$ Ibidem, s. 303.

${ }^{4}$ M. Podgóreczny, Albert Forster. Gauleiter i oskarżony, Gdańsk 1997, s. 367. Zob. także M. Wardzyńska, Wysiedlenia z okupowanych ziem polskich właczonych do III Rzeszy w latach 1939-1945, Warszawa 2017, s. 39 i n. 
Polaków, którzy nie mieli związków krwi z niemczyzną ${ }^{5}$. Himmler, jako komisarz Rzeszy ds. umacniania niemczyzny, raportował na początku 1943 r., że do Generalnego Gubernatorstwa deportowano z Gdańska - Prus Zachodnich 365 tys. Polaków 6 . Tych, którzy nie znaleźli się na volksliście i których nie deportowano, traktowano jako tanią siłę roboczą, wywożono do pracy niewolniczej w starej Rzeszy lub więziono w obozie koncentracyjnym Stutthof ${ }^{7}$. Polska ludność wyjęta została spod prawa i pozbawiona możliwości zaopatrzenia w podstawowe artykuły żywnościowe.

Codzienny terror realizowany był również przez sądy specjalne powołujące się na przepisy karne, stosowane także wobec Polaków opierających się germanizacji, która pociągała za sobą powołania do służby w Wehrmachcie. W sprawozdaniu z programowego wy-

${ }^{5}$ Uczestniczący w posiedzeniu komisji do spraw zniemczenia w Toruniu dnia 22 października 1942 r. Josef Goebbels zapisał w swym dzienniku ocenę: „Myślę że Forster postępuje trochę zbyt wspaniałomyślnie. Mogę sobie wyobrazić, z jakich powodów Forster i Himmler popadli w spór w tej kwestii. [...] Nadal będę śledził rozwój sytuacji, ponieważ ma ona niezwykle doniosłe znaczenie dla przyszłości tej części naszego narodu, która żyje na pograniczu”. Cyt. za: D. Schenk, Albert Forster, s. 304.

${ }^{6}$ D. Schenk, Albert Forster, s. 375. Artur Greiser, gauleiter Kraju Warty, zgodnie $z$ wytycznymi Heinricha Himmlera, planował stworzenie na podległym mu obszarze Polski włączonego do Rzeszy „kraju wzorcowego”, dlatego w instrukcji o zapisywaniu na volkslistę wskazywał kierownikom terenowych organizacji NSDAP: „Polak, choćby przyjęty do wspólnoty niemieckiej, pozostanie Polakiem, wobec tego należy brać tylko tych, którzy mają krew niemiecką, reszta musi być wysiedlona poza okręg”. Szerzej: W. Kulesza, Wysiedlenia $z$ Kraju Warty (Warthegau) $w$ świetle procesu Gauleitera Artura Greisera, w: Ludność cywilna $w$ tódzkich obozach przesiedleńczych, red. J. Żelazko, Łódź 2010, s. 45. Ponieważ władze Kraju Warty w swych decyzjach o wpisywaniu na volkslistę nie przywiązywały większej wagi do niemieckiego pochodzenia, Greiser oświadczył: „postanowiłem, że tylko osoby wywodzące się co najmniej w 50 procentach od Niemców mogą zostać uznane za mające niemieckie pochodzenie”. Cyt. za: C. Epstein, Wzorcowy nazista. Arthur Greiser i okupacja Kraju Warty, przeł. J. Włodarczyk, Wrocław 2010, s. 207. Warunek ten nie był jednakże przestrzegany w realiach pogarszającej się sytuacji na frontach, o czym można wnioskować $z$ twierdzenia Greisera na początku stycznia 1944 r., że „żaden inny okręg nie przeznaczył wyższego odsetka zamieszkałych w nim mężczyzn do służby w Wehrmachcie”. Ibidem, s. 301.

${ }^{7}$ K. Dunin-Wąsowicz, Obóz koncentracyjny Stutthof, Gdańsk 1970, s. 34 i n. 
stąpienia Forstera na wiecu 13 października 1940 r. w Teatrze Miejskim w Gdańsku napisano: „Wśród ożywionego aplauzu [...] gorąco zalecał wszystkim sędziom i prokuratorom, aby zawsze pamiętali, że prawem jest tylko to, co służy narodowi, bezprawiem zaś to, co mu szkodzi"8. Hasło głoszące, że w narodowosocjalistycznym państwie „prawem jest to, co służy nardowi niemieckiemu” stało się uzasadnieniem dla ferowania wyroków skazujących, dla których podstawą było nie literalne znaczenie prawa, lecz „zdrowe poczucie narodowe” sędziów, odwołujących się do „myśli przewodniej” przepisów karnych, które stosowali „odpowiednio”, pomimo że nie zakazywały one zachowań,za które karali ${ }^{9}$. Drakońskie wyroki opierały się na zatem na zasadzie analogii iuris, szeroko stosowanej w praktyce prokuratorskiej i sędziowskiej w III Rzeszy.

\section{Niemiecka lista narodowościowa jako sposób germanizacji}

Decydujące znaczenie dla pełnej realizacji planu narodowościowego gauleitera Forstera miało mieć jego wezwanie („Aufruf!”) z dnia 22 lutego 1942 r. rozplakatowane we wszystkich miejscowościach

8 D. Schenk, op.cit., s. 269. Hasło „Recht ist, was dem Volke nütz” stanowiło podstawę tworzenia i wykładni narodowosocjalistycznego prawa, którego głównym celem była ochrona interesów wspólnoty narodowej dominujących nad wszelkimi prawami indywidualnych osób, a obowiązek kierowania się narodową racją i służenia jej, stał się pierwszą powinnością jurystów (E. Ritter, Justiz und innere Verwaltung, w: Enzyklopädie des Nationalsozialismus, München 1998, s. 94).

${ }^{9}$ Wprowadzony do niemieckiego kodeksu karnego (Strafgesetzbuch - StGB z 1871 r.) przepis § 2 stanowił, że jeżeli w postępowaniu sądowym okaże się, iż oskarżony popełnił czyn zasługujący na ukaranie „według zdrowego poczucia narodowego” („nach gesundem Volksempfinden”), który to czyn jednakże nie jest w ustawie zabroniony, to sąd powinien zbadać, czy czyn ten odpowiada zasadniczej myśli jakiegoś przepisu prawa karnego, przez którego odpowiednie zastosowanie „można by wspomóc zwycięstwo sprawiedliwości”. Szerzej W. Kulesza, Crimen laesae iustitiae. Odpowiedzialność karna sędziów i prokuratorów za zbrodnie sądowe według prawa norymberskiego, niemieckiego, austriackiego i polskiego, Łódź 2013, s. 25. 
okręgu, wzywające Polaków do zgłaszania się na niemiecką listę narodowościową. Obwieszczał w nim, że: „Właśnie teraz, gdy naród niemiecki walczy o swą egzystencję i wolność, musimy mieć jasność, kto, na tych byłych terenach granicznych, uważany jest za Niemica, względnie Polaka. Wielu, którzy w ciągu ostatnich dwudziestu lat nie pokazywali się publicznie jako Niemcy, mogą teraz, przez czynną współpracę, dowieść swej niemieckości”. W innym miejscu napisano, że „ci, którzy czują się Niemcami” („die sich als Deutsche fühlen"), mają ostatnią szansę, żeby znowu stać się członkami niemieckiej wspólnoty narodowej. Dlatego - głosił Forster - „wzywam raz jeszcze wszystkich, którzy czują się Niemcami i chcą być przyjęci do niemieckiej społeczności, żeby zgłaszali się do właściwych burmistrzów lub urzędów komisarzy, lub kierowników miejscowych [NSDAP - przyp. W.K.], lub urzędów ds. niemieckiej volkslisty, w celu pobrania formularza wniosku o wciągnięcie na niemiecką listę narodowościową".

Dla złożenia wniosków, które miały być natychmiast rozpatrzone, wyznaczony został termin „do 31 marca 1942 r.”. Ostrzeżono następnie, że „w przyszłości, a zwłaszcza po zwycięstwie, nie będzie już żadnych widoków na zaliczenie do niemieckiej wspólnoty”. Dalej następowała groźba: „Każdy, kto odrzuci to wezwanie, musi mieć jasność, że w przyszłości nie będzie traktowany jako przynależny do niemczyzny i zostanie oznakowany jako Polak. To, że w ten sposób związany zostanie $z$ najgorszymi wrogami niemieckiego narodu, rozumie się samo przez się”. Natomiast ten, „kto wypełni swój obowiązek złożenia wniosku, pokaże przez to, że chce mieć wszystkie prawa i obowiązki, i chce wnieść swój wkład do ostatecznego zwycięstwa naszego Narodu i Rzeszy"10.

Plakat ten, jako taki, podlegał ochronie prawnokarnej na mocy Polenstrafrechtsverordnung przed wszelkimi zachowaniami Polaków ${ }^{11}$, a jego treść także przed uchybiającymi jej powadze wypowie-

10 Fotokopia tego plakatu w: D. Schenk, op.cit., s. 300.

11 Niczym nieograniczone możliwości karania za jakiekolwiek zachowania stworzone zostały przez przepis ust. 1 pkt. 3 rozporządzenia o postępowaniu karnym przeciwko Polakom i Żydom na włączonych terenach wschodnich (Polenstrafrechtsverordnung) $z$ dnia 4 grudnia 1941 r. (Reichsgesetzblatt I, S. 795): 
dziami Volksdeutschy, kwalifikowanymi na podstawie ustawy z dnia 20 grudnia 1934 r. „przeciwko zdradzieckim zamachom na Państwo i Partię oraz ochronie uniformów partyjnych" (Heimtückegesetz) ${ }^{12}$. Dla wszystkich, którzy czytali apel Forstera, było oczywiste, że po załamaniu się cztery miesiące wcześniej, tzn. w grudniu 1941 r., niemieckiej ofensywy pod Moskwą, Wehrmacht pilnie potrzebował nowych poborowych, którymi stawali się mężczyźni wpisani na volkslistę. Jednakże wypowiedzenie takiej uwagi do innej osoby stanowiło przestępstwo, co zostało potwierdzone w wyroku Sondergerichtu w Grudziądzu z dnia 23 października 1942 r. $^{13}$ skazującym Aloisa Kamińskiego na podstawie paragrafu 2 Heimtückegesetz na trzy lata więzienia $z$ następującym uzasadnieniem: „Po tym jak ze strony gauleitera w Gdańsku wydany został apel, że wniosek

„Oni [Polacy i Żydzi - przyp. W.K.] będą karani śmiercią, a w mniej ciężkich przypadkach karą pozbawienia wolności, jeżeli przez nienawistną lub podburzającą działalność wykazują wrogą wobec Niemców postawę, w szczególności wyrażają się wrogo o Niemcach, zdzierają lub uszkadzają publiczne obwieszczenia niemieckich władz lub służb, albo jeżeli przez swoje inne zachowania obniżają lub szkodzą poważaniu lub dobru Rzeszy niemieckiej lub niemieckiego Narodu”. Tak sformułowany przepis wykorzystywany był przez sądy specjalne jako narzędzie eksterminacji Polaków i uzasadnienie karania śmiercią za czyny niezakazane przez ustawę. W oparciu o jego treść sformułowana została także zasada: „Pełne zniemczenie włączonych terenów wschodnich wymaga, żeby wszelkie płciowe kontakty między Polakami i Niemcami były zabronione i że wykroczenia przeciwko tej zasadzie muszą być karane $z$ całą surowością. Każdy Polak, który uprawia stosunki z Niemką lub niemoralnie się do niej zbliża, musi wiedzieć, że przez to traci on swoje życie" (szerzej W. Kulesza, Sąd Specjalny (Sondergericht) $w$ Łodzi, w: Gmach i jego tajemnice. Sąd Okręgowy $w$ Łodzi 1917-2017, Łódź 2017, s. 74 i n.).

${ }^{12}$ Heimtückegesetz (Reichsgesetzblatt I, s. 1269). Przepis $§ 2$ głosił: „(1) Kto publicznie czyni złośliwe lub podżegające lub wynikające $z$ niskich pobudek wypowiedzi o kierowniczych osobistościach państwa lub NSDAP lub o ich zarządzeniach lub o instytucjach, które zdatne są podkopać zaufanie narodu do politycznego kierownictwa, będzie karany więzieniem. (2) Niepubliczne złośliwe wypowiedzi uznaje się za równoznaczne $z$ wypowiedziami publicznymi, jeżeli sprawca liczył się lub musiał liczyć się z tym, że jego wypowiedź dotrze do publiczności”.

${ }^{13}$ 5/4 Sg. KMs. 10/42. SG 190/42, Archiwum Federalne w Berlinie, DAHL RJM - IV g 7 Nr. Des Aktenbandes 120/42. 
każdego, kto chciałby zostać wpisany na niemiecką listę narodowościową, w krótkim terminie zostanie rozpatrzony, [oskarżony] wyraził się do świadka Jobsta, który jest Volksdeutschem: "Teraz widać, jak źle jest z Niemcami. Teraz potrzebują już Polaków do Wehrmachtu". $Z$ akt sprawy wynika, że oskarżony Kamiński pięć miesięcy przed skazaniem został wpisany w dziale III niemieckiej listy narodowościowej, lecz najwyraźniej nie wierzył w ostateczne zwycięstwo „narodu niemieckiego i Rzeszy”, o czym świadczy, uznana za przestępstwo w tym samym wyroku skazującym, jego wypowiedź do świadka Mecka: „Uważaj, bo kiedy tu znowu będzie Polska, to ja ci pokażę”. Miał także złośliwie przepowiadać: „Nie będzie długo trwało, jak wy będziecie jeść nieobrane kartofle i otręby, a my kiełbasę”. Wypowiedzi te zostały uznane za „nienawistne, $z$ niskich pobudek, o kierowniczych osobistościach państwa i NSDAP i o ich zarządzeniach", mające miejsce niepublicznie, lecz mogły być dalej rozpowszechniane, co uzasadniało ukaranie $z$ odpowiedniego przepisu Heimtückegesetz.

Apel Forstera krytykowany był także przez Himmlera, pełnomocnika Hitlera do spraw umacniania niemczyzny w Gdańsku i Prusach Zachodnich, oraz przez wyższego dowódcę SS i policji Richarda Hildebrandta, który informował władze w Berlinie, że publicznie ogłoszona groźba Forstera zaliczenia wszystkich, którzy nie złożą wniosku, do najgorszych wrogów państwa i czekających ich konsekwencjach spowodowała, że „Polacy zgłaszają się z obawy, że zostaną zesłani do obozu lub wywiezieni do Generalnego Gubernatorstwa” ${ }^{14}$. Alarmował, że obserwuje się coraz liczniejsze przypadki dezercji i defetyzmu wśród mężczyzn zaciągniętych do Wehrmachtu z listy numer III. Wskazywał, że konieczne jest „wyeliminowanie elementów niepewnych”, co oznaczało ich "prewencyjne” wymordowanie ${ }^{15}$. W tajnych raportach przesyłanych Himmlerowi informowano także, że wykrywani członkowie polskiego ruchu oporu często figurowali na trzeciej liście narodowościowej ${ }^{16}$.

14 Raport Hildebrandta z dnia 31 października 1942 r. (D. Schenk, op.cit., s. 302-303).

15 Ibidem, s. 302.

16 D. Schenk, op.cit., s. 350. 
Poniżej zostaną przedstawione dwa wyroki Sądu Specjalnego w Toruniu, ukazujące sposób postępowania $z$ wpisanymi na volkslistę Polakami, którym postawiony został zarzut uchylania się od służby w niemieckim wojsku.

\section{Rezygnacja $z$ wpisu na volkslistę jako zbrodnia osłabienia mocy obronnej}

Wyrokiem Sądu Specjalnego w Toruniu z dnia 19 maja 1942 r. ${ }^{17}$ Wenzeslaus Zydel za zbrodnię uchylania się od służby wojskowej został skazany na karę śmierci. Jako podstawę prawną skazania przyjęto § 5 (1) Ziff. 3 rozporządzenia o specjalnym wojennym prawie karnym $z$ dnia 17 sierpnia $1938 \mathrm{r} .{ }^{18} \mathrm{~W}$ toku postępowania ustalony został stan rzeczy poprzedzający popełnienie zarzucanej zbrodni: „Oskarżony Zydel był w polskim czasie Polakiem z przekonania. Nie starał się także o uznanie go za Volksdeutscha. 26 listopada 1941 r. został on, jego żona i dwoje dzieci, a także jego ojciec, wpisani na niemiecką listę narodową w części III, po czym 4 grudnia 1942 r. wręczono im zieloną legitymację niemieckiej listy narodowej $^{19}$. W dniu 20 stycznia 1942 r. wziął Zydel pierwszy raz udział

174 Sg. K.Ls. 45/42, Archiwum Federalne w Berlinie, DAHL - NJ - 2964.

${ }_{18}$ Kriegssonderstrafrechtsverordnung (KSSVO) z dnia 17 sierpnia 1938 r., (Reichsgesetzblatt 1939 I, S. 1455) stanowił w § 5 (1) Ziff. 3: „Za osłabienie mocy obronnej będzie karany śmiercią [...] kto w celu całkowitego, częściowego lub czasowego uchylania się samemu lub innej osoby od obowiązku służby wojskowej dokonuje samookaleczenia lub posługuje się środkiem obliczonym na oszustwo lub innym sposobem”.

19 Do grupy trzeciej Volksdeutschów zaliczano osoby, które pomimo wcześniejszych związków $\mathrm{z}$ polskością odnajdywały się ponownie $\mathrm{w}$ niemczyźnie lub posiadały dominującego w związku niemieckiego współmałżonka, a także osoby posługujące się ojczystym językiem słowiańskim, lecz ze względu na związki krwi i kulturowe sympatyzowały z niemczyzną. Osoby te wpisane na listę, określaną jako „pośrednia”, otrzymywały dowód przynależności do niemczyzny warunkowo - do odwołania. Na listy nr I i II przyjmowano Niemców, którzy przed wojną aktywnie manifestowali swoją narodowość lub dowiedli, że zachowali swą niemieckość, co dawało im obywatelstwo Rzeszy. Na liście nr IV umieszczano osoby pochodzenia niemieckiego, które „spolonizowały się 
w wieczorze szkoleniowym NSDAP dla należących do części III volkslisty. Prowadzący szkolenie zwracał przede wszystkim uwagę na obowiązki, które niesie za sobą wyznanie przynależności do niemczyzny. I tak, nie wolno w rodzinach mówić nadal po polsku, lecz musi być używany tylko język niemiecki. W razie zlekceważenia tych obowiązków grożą surowe kary. Mówca dodał, że ten, kto nie mógłby szczerze nastawić się na takie zachowanie, powinien, najlepiej już jutro rano, zwrócić swój ausweis w urzędzie starostwa (Landratsamt)" 20 .

Zarzucane oskarżonemu naganne zachowanie polegać miało na tym, że nie dostarczył fotografii do książeczki wojskowej i nie zgłosił się do wojskowego urzędu meldunkowego w celu rejestracji do służby. W odpowiedzi na wojskowe wezwanie 31 stycznia $1942 \mathrm{r}$. odesłał do urzędu Landrata nadane mu i jego żonie „zielone dokumenty" Volksdeutschy, wraz z pismem zawierającym prośbę o skreślenie obojga $z$ volkslisty. W uzasadnieniu Zydel napisał: „Na wieczorze szkoleniowym zwrócono nam uwagę na to, że ten, kto nadal czuje się Polakiem, lepiej, żeby zwrócił ausweis. Czynię zadość temu wezwaniu razem $z$ moją rodziną, ponieważ wewnętrznie czuję się Polakiem”. Do wojskowego urzędu meldunkowego napisał Zydel kilka dni później następujące oświadczenie: „Na wezwanie do poboru informuję, że nie jest mi wiadomym, że pozostaję w służbowym stosunku do niemieckiego Wehrmachtu. Posiadałem przedtem polskie obywatelstwo, a w tym momencie nie posiadam żadnego innego obywatelstwa".

Kwalifikację prawną tak opisanego zachowania, jako uchylania się przez oskarżonego od służby w Wehrmachcie w wyniku oszustwa, uzasadniono w wyroku, posługując się analogią iuris, legitymowaną przez $\S 2$ StGB ${ }^{21}$. Napisano: „Jeżeli nie zastosować bezpośrednio do takiego sprawcy $\S 5$ (1) Ziff. 3, to trzeba spojrzeć

całkowicie i występowały czynnie przeciwko Niemcom, obecnie jednak złożyły wnioski o wpisanie na niemiecką listę narodowościową”. Wszyscy wpisani na listy mieli prawa nieprzysługujące Polakom, w tym większe przydziały żywności.

${ }^{20}$ Todesurteil gegen Wenzeslaus Zydel, IV g 22 1500/42, Archiwum Federalne w Berlinie, DAHL - NJ - 2964.

${ }^{21}$ Zob. przypis 9. 
na jego czyn, jako karygodny co najmniej według zasadniczej myśli tego przepisu i zdrowego poczucia narodowego". I dodano, że nieukaranie oskarżonego spowodowałoby, „że wpisani na niemiecką volkslistę w dziale III, jako starający się o obywatelstwo, mogliby wbrew prawu popełniać czyny w celu uchylenia się od obowiązującej ich służby wojskowej”. W zakończeniu wywodu zaznaczono: „Niemiec, a także Volksdeutsch znajdujący się w położeniu oskarżonego, który nie jest gotów w chwili wielkiego niebezpieczeństwa dla Narodu i Rzeszy bronić kraju, nie może liczyć na łaskę”. Sędziowie, którzy wydali wyrok skazujący oskarżonego na karę śmierci (Breier, Deike, dr von Groschopff), sporządzili pismo z tą samą datą (19 maja 1942 r.) stwierdzające, że „Zydel, który był bez wątpienia zadeklarowanym Polakiem i nie starał się o uznanie go za Volksdeutscha”, nie zasługuje na ułaskawienie, ponieważ „odesłał on ausweis tylko po to, żeby nie stać się żołnierzem, co jest w najwyższym stopniu zarzucalne”, tj. decydujące o ciężarze jego winy”. Wykonanie wyroku zdaniem sędziów „będzie także odpowiednią szkołą, ponieważ właśnie teraz kwestia służby wojskowej przez dużą część osób wpisanych w dziale III volkslisty jest odczuwana jako nieprzyjemny skutek zniemczenia (Eindeutschung)". Takie samo stanowisko zajął wyższy prokurator przy Sondergerichcie w Toruniu i przekazał je prokuratorowi generalnemu w Gdańsku, a ten, proponując, żeby „pozostawić wolną drogę sprawiedliwości”, przesłał dokumenty do ministra sprawiedliwości w Berlinie, któremu z upoważnienia Führera Rzeszy przysługiwało prawo łaski.

\section{Skarga o nieważność}

Zaznaczyć trzeba w tym miejscu, że lektura kolejnych dokumentów zawartych $\mathrm{w}$ badanym tomie akt zaskakuje badacza, ponieważ skazujące na karę śmierci wyroki sądów specjalnych, ferowane $\mathrm{w}$ jednoinstancyjnym postępowaniu i zakończone formułą stwierdzającą ich wykonalność („Das Urteil ist vollstreckbar”), wracały $z$ reguły $z$ deklaracją ministra sprawiedliwości: „Z przyznanego przez Führera prawa łaski nie korzystam i pozostawiam wolną drogę sprawiedliwości”, po czym następowała egzekucja skazanego. 
W toku referowanego postępowania tak się jednak nie stało, a to za sprawą skargi o nieważność opartej na znajdujących się w aktach opiniach prawnych, w których stwierdzono, że według obowiązującego w czasie czynu oskarżonego rozporządzenia z 4 marca $1941 \mathrm{r}$. „o niemieckiej volksliście i niemieckim obywatelstwie na włączonych terenach wschodnich", sam fakt wpisania na volkslistę w jej części III byłego obywatela polskiego nie oznaczał jeszcze nadania mu niemieckiego obywatelstwa (Einburgerung) ${ }^{22}$. Ministerialny referent sprawy sporządził stanowisko „w sprawie Zydel” zawierające stwierdzenie, że „skazanie nie może być skuteczne” i wskazał racje dla wniesienia skargi o jego nieważność przez prokuratora Rzeszy przy Sądzie Najwyższym, co nastąpiło 18 sierpnia $1942 \mathrm{r}^{23}$

22 Skarga o nieważność (Nichtigkeitsbeschwerde) została wprowadzona rozporządzeniem z dnia 21 lutego 1940 r. o właściwości sądów karnych, sądów specjalnych i przepisach postępowania karnego (Reichsgesetzblatt I, S. 405) jako środek uchylenia prawomocnego wyroku wydanego przez każdy sąd karny. Prawo do wniesienia tej skargi do Sądu Najwyższego Rzeszy przysługiwało wyższemu prokuratorowi przy tym sądzie, jeżeli stwierdził, że „wyrok z powodu błędu przy zastosowaniu prawa do ustalonych faktów jest niesprawiedliwy (ungerecht)" (§ 34). Jej stosowanie w sprawach Polaków skazanych na kary uznane za zbyt łagodne $\mathrm{z}$ reguły prowadziło do karania ich śmiercią w powtórzonym postępowaniu. Przykład w: W. Kulesza, Crimen laesae iustitiae, s. 35.

${ }^{23} \mathrm{~W}$ kwestii karalności za zbrodnię uchylania się od służby wojskowej najdalej posunięte rozumowanie oparte na „zdrowym poczuciu narodowym” prokuratora i sędziów znalazło wyraz w wyroku wydanym przez Sondergericht w Grudziądzu skazującym na karę śmierci Bernarda Kruczinskiego. Oskarżony pomimo, że nie złożył wniosku o wpisanie go na volkslistę, to jednak ubiegał się o zgodę na małżeństwo $z$ Volksdeutschką, a zapytany przez policyjnego urzędnika o służbę wojskową powiedział: „będę służył, jeśli będę musiał”. Słowa te uznane zostały przez Sąd Specjalny za wystarczające dla skazania Kruczinskiego za uchylanie się od służby wojskowej na podstawie tego samego przepisu, jak w sprawie Wenzeslausa Zydla, tj. § 5 (1) Ziff. 3 (KSSVO). W obu sprawach złożona została w tym samym czasie skarga do Reichsgerichtu o nieważność wyroków. W sprawie skazanego Kruczinskiego zastosowanie analogii przez sędziów karzących oskarżonego śmiercią uznane zostało za idące zbyt daleko, jako że sens wypowiedzianych przez niego słów wyrażał gotowość do służby - ,jeżeli będę musiał” - nie zaś zamiar uchylenia się od niej. W sprawie tej sporządzone zostały opinie prawne, które załączono także do akt Zydla. Według opinii Oberkomando der Wehrmacht (z dnia 24 marca 1942 r.) słowa skazanego nie świadczyły o jego subiektywnym przekonaniu ani liczeniu się 
Reichsgericht rozpatrzył skargę o nieważność 28 września $1942 \mathrm{r}^{24}$, uchylając wyrok wydany przez Sondergericht w Toruniu ze stwierdzeniem, że „sam fakt wpisania byłego polskiego obywatela w dziale III niemieckiej volkslisty nie wystarcza do uzasadnienia obowiązku służby wojskowej”.

Ze względu na znaczenie tego wyroku dla zagadnienia powoływania Polaków do służby w Wehrmachcie celowe wydaje się prześledzenie sekwencji rozumowania zawartego $\mathrm{w}$ postanowieniu o uchyleniu wyroku skazującego. W punkcie wyjścia uzasadnienia przypomniano: „Sondergericht in Thorn skazał oskarżonego za zbrodnię według § 5 ust. $1 \mathrm{Nr} 3 \mathrm{KSSVO}$ na karę śmierci. Sąd ten przyjął, że oskarżony, pomimo że nie posiadał niemieckiego obywatelstwa, to zobowiązany był do służby jako wpisany w dziale III niemieckiej listy narodowościowej. Poprzez zwrócenie zielonej legitymacji i przez oszukańcze oświadczenia wobec Landrata (starosty) oraz urzędu nie wolno mu było, jako przyszłemu niemieckiemu obywatelowi, uchylać się od swego obowiązku służby w obronie [Rzeszy]”. Dlatego Sondergericht uznał, że § 5 ust. 1 Nr 3 KSSVO „powinien znaleźć co najmniej odpowiednie zastosowanie” jako podstawa skazania na karę śmierci. Dalej napisano: „Przeciwko wyrokowi

z tym, że jest zobowiązany do służby wojskowej i jako takie nie stanowiły uzasadnienia dla wyroku śmierci za zmierzone uchylanie się od służby wojskowej (Strafsache gegen Kruczinski, IV g 22 1248/42, Archiwum Federalne Berlinie, DAHL - NJ - 2964). W opinii ministra spraw wewnętrznych (z dnia 8 czerwca 1942 r.) zaznaczono, że warunkiem skazania za taką zbrodnię jest posiadanie niemieckiego obywatelstwa, którego Bernard Kruczinski nie miał, a jego wypowiedź wobec urzędnika „nie była zdatna do realizacji uchylenia się od służby wojskowej”. W tej samej opinii skierowanej do ministra sprawiedliwości Rzeszy alarmowano: „W szczególności z Kraju Rzeszy Gdańsk - Prusy Zachodnie donosi się, że wszelkie możliwe, lecz nieuprawnione do tego władze, a szczególnie placówki służbowe NSDAP, wydają niemieckie ausweisy na podstawie całkowicie niejednolitych zasad”. Wskazano kategorycznie, że byłym obywatelom polskim może być przyznana niemiecka przynależność narodowa tylko na podstawie obiektywnych faktów, jeżeli także pod polskim panowaniem jasno i jednoznacznie deklarowali się jako należący do niemczyzny (Der Reichsminister des Innern an Herrn Reichsminister der Justiz, IV g 22 1248/42, DAHL - NJ - 2964).

${ }^{24} 5$ C 33/42, IV g 22 1500/42, Archiwum Federalne w Berlinie, DAHL $\mathrm{NJ}-2964$. 
Sądu Specjalnego została wniesiona przez najwyższego prokuratora skarga o nieważność, której uzasadnienie uznane zostało za słuszne, ponieważ: "1) Według ustawy o obronności do służby zobowiązany jest każdy Niemiec, tj. każdy obywatel Rzeszy. Tylko zobowiązany mógłby uchylić się od służby w obronie. Co do osób, które nie są zobowiązane, nie istnieje żaden obowiązek pełnienia służby wojskowej, od którego mógłby się on uchylić. 2) Oskarżony bez wątpienia nie był niemieckim obywatelem. Odpowiednio do zarządzenia o niemieckiej volksliście na włączonych terytoriach wschodnich z 4 marca 1941 r. (RGB I S. 118) został on 26 listopada 1941 r. wciągnięty na niemiecką volkslistę w dziale III [...] jako były obywatel polski i mógłby następnie otrzymać niemieckie obywatelstwo. [...] 4) Z zarządzenia Ministerstwa Sprawiedliwości z 7 marca 1940 r. - I Rb 604/40 IV - 500/4 - Rejestracja i pobór na włączonych terenach wschodnich i z zarządzenia Dowództwa Wehrmachtu z 16 maja 1941 r. wynika, że sam fakt wpisania byłego obywatela polski w dziale III niemieckiej volkslisty nie wystarcza do uzasadnienia obowiązku służby wojskowej “”.

Podkreślone zostało, że dopiero drugie zarządzenie o niemieckim obywatelstwie na włączonych terenach wschodnich z 31 stycznia 1942 r. (RGB I S. 51) stanowiło o tym, iż równocześnie $z$ wpisem w dziale III volkslisty osoba otrzymuje obywatelstwo Rzeszy. Stwierdzono, że w czasie przewinienia oskarżonego (odesłał ausweis 31 stycznia 1942 r.) owo drugie zarządzenie nie weszło jeszcze w $\dot{z} y-$ cie. Dalej napisano, że „oskarżony jest typowym przedstawicielem tzw. zawieszonego ludu (schwebenden Volkstums), tzn. nie jest on jednoznacznie ani Polakiem, ani Niemcem” i dlatego ,jest wątpliwe, czy w ogóle uzyska on obywatelstwo".

Konkluzja głosiła, że „byli polscy obywatele dopóty nie będą zobowiązani do obrony Rzeszy, dopóki nie uzyskają niemieckiego obywatelstwa, co sprawia, że wykluczone jest zastosowanie do nich $\S 5$ ust 1 KSSVO do uzasadnienia ich obowiązku, jako ludzi polsko nastawionych, do przymusowego odbycia służby wojskowej”. Dlatego „uchylony wyrok skazujący oskarżonego, który nie posiadał niemieckiego obywatelstwa, jako oparty na błędnych rozważaniach prawnych jest niesprawiedliwy (ungerecht)". Do tego miejsca wywód Reichsgerichtu nie budzi zastrzeżeń, co do zgodności z powołanymi 
przepisami niemieckiego prawa. Tym większe zaskoczenie czytelnika powyżej zreferowanego wyroku wywołuje jego zakończenie, sprawiające wrażenie, że zostało niejako dopisane jako wyraz „zdrowego poczucia narodowego sędziów" i nie łączy się logicznie z tym, co zostało wcześniej przez sąd wywiedzione: „Nie wystarcza to jednak do natychmiastowego uniewinnienia oskarżonego przez sąd specjalny. Nie można $z$ konieczną pewnością stwierdzić, że oskarżony nie jest winny usiłowania uchylenia się od służby wojskowej”. Uchylając wyrok, skierowano sprawę do ponownego rozpatrzenia $z$ jednoznaczną wskazówką co do oczekiwanego skazania za usiłowanie zbrodni $^{25}$. Oznaczało to, że zamiast kary śmierci wymierzona ma zostać oskarżonemu kara ciężkiego więzienia od 3 do 15 lat (§ 44, $\S 14$ StGB) ${ }^{26}$.

Wewnętrzna sprzeczność przytoczonego orzeczenia widoczna jest w zestawieniu zdania głoszącego, że tego, kto nie jest niemieckim obywatelem, nie można „doprowadzać przymusem do służby wojskowej” z jednoczesnym wskazaniem sądowi specjalnemu, że powinien go jednak skazać za usiłowanie uchylania się od tej służby. Zastosowanie takiej konstrukcji przez Reichsgericht miało, jak się wydaje, na celu to, żeby Polak, który nie zabiegał o niemieckie obywatelstwo, lecz po otrzymaniu wezwania do poboru, nie stawił się na nie, nie uniknął kary. Reichsgericht najwyraźniej spostrzegł, że w pierwszej części wywodu wskazał, że Polak bez niemieckiego obywatelstwa nie może podlegać karze, jeżeli nie zgłosi się na wezwanie do poboru. Dlatego stwierdził następnie, że taka osoba jednak powinna zostać ukarana za usiłowanie uchylenia się od służby wojskowej, co zgodnie $z$ niemieckim prawem jest zbrodnią.

Trudno byłoby przy tym przypuszczać, że sędziowie Reichsgerichtu nie zdawali sobie sprawy $z$ tego, że zachowania Zydla, od-

${ }^{25}$ Przepis § 43 StGB opisywał usiłowanie jako zachowanie tego, „kto zamiar popełnienia zbrodni lub występku okazuje czynami stanowiącymi początek wykonania” przestępstwa.

${ }^{26}$ Usiłowanie było „karane łagodniej niż dokonanie”, przy czym, ,jeżeli za dokonanie zbrodni grozi kara śmierci [...] wówczas kara ciężkiego więzienia nie będzie niższa od trzech lat” (§ 44 StGB). Skazanie na karę ciężkiego więzienia pociągało za sobą "stałą niemożność odbywania służby w armii niemieckiej” (§ 31 StGB). 
rzucającego niemieckie obywatelstwo, nie można było jurystycznie uznać za usiłowanie (tj. początek dokonania zbrodni) uchylania się przez obywatela Rzeszy od służby w Wehrmachcie. Według ówczesnego powszechnie przyjmowanego komentarza do Kodeksu karnego usiłowanie, jako karalny początek wykonania zbrodni, zachodzi wtedy, "gdy już samo zachowanie sprawcy stwarza bezpośrednie niebezpieczeństwo dla prawnie chronionego dobra" ${ }^{27}$. W sytuacji, w której nie istniał prawny obowiązek służby, ponieważ mężczyzna nie miał niemieckiego obywatelstwa, nie można było karać go za usiłowanie, rozumiane jako stworzenie bezpośredniego niebezpieczeństwa dla dobra prawnego, jakim była powinność posłuchu poborowego. Stanowisko Reichsgerichtu oznaczało w istocie, że osoby niemające obywatelstwa rodzącego obowiązek służby wojskowej także można do niej zmusić, stosując groźbę karania za usiłowanie uchylenia się od obowiązku, który ich nie dotyczył. W takich przypadkach, jak wspomniano, najniższą karą za usiłowanie zbrodni były trzy lata ciężkiego więzienia, którą w stosunku do Polaków wykonywano w obozach karnych o zaostrzonym rygorze, gdzie skazani zwykle nie przeżywali dłużej aniżeli sześć miesięcy ${ }^{28}$.

Komentarz do obu zreferowanych powyżej wyroków sprowadzić trzeba do konstatacji, że w ich treści dokonane zostało sędziowskie przestępstwo naginania prawa ${ }^{29}$.

27 A. Dalcke, Strafrecht und Strafverfahren, Berlin-München 1940, s. 41.

${ }^{28}$ J. Waszczyński, Z działalności hitlerowskiego Sądu Specjalnego $w$ Łodzi $w$ Łodzi (1939-1945), „Biuletyn Głównej Komisji Badania Zbrodni Hitlerowskich w Polsce” 1972, t. XXIV, s. 77.

29 Kodeks karny Rzeszy Niemieckiej z 1871 r. stanowił, że podlega karze „urzędnik” (Beamter; w pierwszej kolejności sędzia), „który, prowadząc lub rozstrzygając sprawę prawną, umyślnie (vorsätzlich) nagina prawo na korzyść albo na niekorzyść jednej ze stron, ulegnie karze ciężkiego więzienia do lat pięciu" (§ 336 StGB). Nagięcie prawa w wyroku Sondergerichtu w Toruniu polegało na skazaniu na karę śmierci Polaka za uchylanie się od służby wojskowej, pomimo że nie był obywatelem Rzeszy i nie miał on takiego obowiązku, na co zwrócił uwagę Reichsgericht. Skazanie na karę śmierci stanowiące rezultat nagięcia prawa stanowiło w tym przypadku równocześnie usiłowanie morderstwa, gdyż wyrok z przyczyn niezależnych od sędziów nie został wykonany. Sędziowie Reichsgerichtu (Klingsporn - przewodniczący, dr Schäfer, dr Rohde, dr Iber, dr Everling) w końcowej części swego orzeczenia zawierającego wskazanie, że 


\section{Wpis na volkslistę a niemieckie obywatelstwo}

Sędziowie Sądu Specjalnego w Toruniu, do którego wróciła sprawa Zydla z poleceniem ponownego jej rozpatrzenia, musieli poczuć się zirytowani, że w treści wiążącego wyroku Reichsgerichtu niejako okrężną drogą zostało im nakazane wymierzenie oskarżonemu kary poprzez skazanie go za usiłowanie uchylenia się od służby wojskowej. W swym pierwszym wyroku - co trzeba powtórzyć - zastosowali prostą formułę opartą na analogii iuris i skazali oskarżonego na karę śmierci poprzez „odpowiednie” powołanie przepisu $§ 5$ ust 1 KSSVO. Ich irytacja widoczna jest natomiast w drugim wyroku z 17 grudnia $1942 \mathrm{r}^{30}$ wydanym w tej samej sprawie. Napisali w nim, że oskarżonemu, niemającemu w czasie zarzuconego mu czynu - według ustaleń Reichsgerichtu - niemieckiego obywatelstwa, nie można udowodnić zamiaru uchylenia się od obowiązku służby wojskowej, gdyby dopiero w przyszłości otrzymał on to obywatelstwo połączone $z$ powinnością stawienia się w szeregach Wehrmachtu. Dlatego nie postąpili w sposób wskazany im przez Reichsgericht, stwierdzając, że brak jest dowodów na to, że oskarżony Zydel działał z zamiarem przyszłego, albowiem możliwego dopiero po otrzymaniu obywatelstwa, uchylania się od służby wojskowej. Zamiar taki

Polak ma zostać skazany za usiłowanie uchylenia się w przyszłości od służby w Wehrmachcie, także dokonali przestępstwa nagięcia prawa. W obu wyrokach przeprowadzono subsumcję zachowania oskarżonego pod przepis o osłabianiu mocy obronnej, którego znamiona nie zostały przezeń wypełnione. Przepis $\S 336$ StGB o sędziowskim przestępstwie pozostał jednak martwy, ponieważ po wojnie przyjęto, że odpowiedzialność sędziów powstaje tylko wówczas, gdy z zamiarem bezpośrednim naginali oni prawo, a działania $z$ takim zamiarem nie można było im udowodnić. W Republice Federalnej Niemiec jako zasada przyjęte zostało twierdzenie Hansa Filbingera, nazistowskiego sędziego marynarki wojennej, który brał udział w wydawaniu wyroków śmierci: „to, co wówczas było prawne, nie może być dziś uznane za bezprawie” - „Was damals rechtens war, kann heute nicht Unrecht sein” (M. Sagenschneider, 50 Klassiker Processe, Hildesheim 2005, s. 198).

30 4. Sg. K. Ls. 45/42, IV g 22 1047/43, Archiwum Federalne w Berlinie, DAHL - NJ - 2964. 
był natomiast koniecznym warunkiem skazania go za usiłowanie dokonania przestępstwa.

Sąd Specjalny, ponownie orzekając w tej sprawie, uznał ostatecznie, że oskarżony Zydel winny jest tylko popełnienia dwóch wykroczeń polegających na nieprzesłaniu swych fotografii do urzędu rejestracyjnego i niestawieniu się osobiście w tym urzędzie pomimo pisemnego wezwania, za co skazany został na karę sześciu tygodni aresztu, która uznana została za odbytą w czasie osadzenia go $\mathrm{w}$ areszcie pod zarzutem popełnienia zbrodni uchylenia się od służby wojskowej ${ }^{31}$.

Dalsze losy Zydla nie są znane, przy czym wątpić można, czy odzyskał on wolność, ponieważ znane są przypadki, w których Gestapo aresztowało na sali sądowej dopiero co uniewinnionego oskarżonego i na podstawie decyzji o prewencyjnym areszcie (Schutzhaft) posyłało go do obozu koncentracyjnego ${ }^{32}$. Prawdopodobne było także zamordowanie go $\mathrm{z}$ polecenia doraźnego sądu policyjnego, niepodlegającego żadnej kontroli i natychmiast wykonywanego ${ }^{33}$. O zmuszaniu Polaków w Kraju Warty do składania wniosków o wpis na Volkslistę zeznawał świadek Paweł Schmidt w procesie Artura Greisera przed Najwyższym Trybunałem Narodowym ${ }^{34}$.

${ }^{31}$ Podstawę stanowiły przepisy o areszcie ochronnym (Schutzhaft) zawarte w Reichstagbrandverordnung z dnia 28 lutego 1933 r., które wyłączały takie uwięzienie spod jakiejkolwiek kontroli ze strony innych organów państwowych. Zarządzenie z dnia 25 stycznia 1938 r. stanowiło, że ten środek przymusu (Zwangsmaßname) jest stosowany do każdego (bez względu na jego obywatelstwo), „kto przez swoje zachowanie zagraża stałości narodu lub państwa”.

${ }^{32}$ W. Kulesza, Crimen laesae iustitiae, s. 24.

${ }^{33}$ W Stutthofie sądowi takiemu przewodniczył szef Gestapo Helmut Tanzmann (D. Schenk, op.cit., s. 343).

${ }^{34}$ Świadek ten zeznał: „Zostałem aresztowany za to, że nie chciałem przyjąć niemieckiej narodowości. W 1943 r. miałem 29 lat, czyli wiek, w którym dozwolono małżeństw. Złożyłem wniosek i wszystkie papiery w Urzędzie Stanu Cywilnego. Urząd [...] odesłał papiery na Volkslistę. Z Volkslisty otrzymałem do wypełnienia bezpośrednio potem kwestionariusze dotyczące narodowości niemieckiej. Odpisałem, że nie stawiałem wniosku o przyjęcie na Volkslistę, uważając się za Polaka. Na list ten otrzymałem wezwanie na gestapo. Urzędnik, który mnie przesłuchiwał w gestapo od razu w ordynarny sposób, krzycząc, zapytał mnie dlaczego nie wypełniłem kwestionariusza. Odpowiedziałem tak 


\section{Samookaleczenie a zbrodnia osłabienia mocy obronnej}

Sędziowskie zdrowe poczucie narodowe znalazło również wyraz w wyroku Sądu Specjalnego w Toruniu z 15 października 1942 r. ${ }^{35}$ skazującym Wacława Miszalowskiego na karę śmierci za uchylanie się od służby wojskowej na podstawie tego samego przepisu jak w powyższej sprawie - 5 (1) Ziff. 3 KSSVO. O oskarżonym napisano w sądowych aktach: „25-letni, katolik, jeszcze niekarany, robotnik rolny, ożenił się w lutym 1942 r. z o 10 lat starszą Agnes Draws, która urodziła w czerwcu tego roku dziecko, zmarłe po trzech tygodniach, 4 lipca 1942 r. Żona oskarżonego jest niemieckiej krwi, dlatego została wpisana na niemiecką volkslistę w dziale III. Oskarżony pochodzi od polskich rodziców i ledwo rozumie niemiecki, wciągnięty został na volkslistę $z$ powodu niemieckiego pochodzenia jego żony, na swój wniosek. W dniu 26 czerwca 1942 r. został on zarejestrowany, wręczono mu zaświadczenie o gotowości do służby wojskowej i ustnie poinformowano, że musi się liczyć z rychłym powołaniem. Wkrótce po tym powiedział on do pracownicy, że najgorsze jest to, że musi iść do wojska i co będzie $z$ jego żoną. W dniu 11 lipca 1942 r., około godziny 8, odciął sobie siekierą cztery palce lewej ręki, rzekomo, żeby odejść od pracodawcy, Niemca, przesiedleńca $z$ Wołynia, bo ten miał go szykanować”.

jak poprzednio na kwestionariusz. Podał mi termin do namysłu: osiem dni. Ja na termin ten się nie zgodziłem, ponieważ oświadczyłem, że w osiem dni swego stanowiska nie zmienię. Wobec tego wyrzucił mnie na korytarz i kazał mi się jeszcze przez dwie godziny namyślać. W tym czasie do jego pokoju wchodził szereg osób w tej samej sprawie i o tym, jakie były wyniki, świadczy fakt, że wiele $z$ nich, widocznie pod przymusem listę tę podpisywało”. Dalej świadek opisał tortury, jakim poddawani byli więźniowie obozu karno-śledczego w Żabikowie, do którego go zesłano decyzją gestapo (Proces Artura Greisera przed Najwyższym Trybunałem Narodowym, Główna Komisja Badania Zbrodni Niemieckich w Polsce, Warszawa 1946, s. 58-59).

354 Sg. K. Ls. 208/42, IV g 22, 2099/42, Archiwum Federalne w Berlinie, DAHL - RJM - 2099/42. 
Sondergericht (Breier jako przewodniczący, Deike, dr von Grosschopff) odrzucił tłumaczenie oskarżonego o szykanowaniu, od którego chciał się uwolnić, i uznał, że celem samookaleczenia było uchylenie się od służby wojskowej przez zobowiązanego do niej ze względu na posiadanie niemieckiego obywatelstwa. Przyjęto, że Miszalowski stał się niemieckim obywatelem już z chwilą wpisania go w dziale III volkslisty, gdyż tak właśnie stanowiło drugie rozporządzenie z 31 stycznia 1942 r. o niemieckiej liście narodowej, zmieniające wcześniejszą regulację, która nie łączyła takiego wpisu $z$ nadaniem obywatelstwa. Zaznaczono, że we wcześniej osądzonej „sprawie Zydel” owo rozporządzenie zmieniające nie obowiązywało w czasie, kiedy ówcześnie oskarżony Zydel dopuścił się przypisanych mu wykroczeń. Sentencja wyroku głosiła, że oskarżony Miszalowski zostaje skazany na podstawie „§ 5 Abs. 1 Ziff. 3 der Kriegssonderstrafrechtsverordnung zum Tode”, ponieważ sam się okaleczył, a jego zamiar uchylenia się od służby wojskowej sąd uznał za udowodniony. Wyrok skazujący Wacława Miszalowskiego na karę śmierci został przekazany do ministerstwa sprawiedliwości w Berlinie z opiniami prokuratora przy Sądzie Specjalnym w Toruniu i prokuratora generalnego w Gdańsku, stwierdzającymi, że „ze względu na ciężar tego przypadku i potrzebę ogólnego odstraszania” kara powinna zostać wykonana.

Stanowisko ministerstwa sprawiedliwości z 8 grudnia $1942 \mathrm{r}$. opierało się na konstatacji, że obowiązek skazanego dotyczący odbycia służby w wojsku został wyczerpująco ustalony, zaznaczono również, że: „Usiłowanego naruszenia obowiązku służby wojskowej dopuściłby się skazany także, gdyby nie posiadał niemieckiego obywatelstwa" ${ }^{36}$. Ministerstwo podkreśliło zatem, że oczekiwane jest karanie Polaków wpisanych na volkslistę za wszelkie próby uniknięcia poboru do wojska, także w tych przypadkach, gdy nie byli obywatelami Rzeszy (Miszalowski nim był). W ten sposób jako zasadę karania przyjęto twierdzenie Reichsgerichtu sformułowane w ostatniej części orzeczenia w sprawie Zydla. Oznaczało to również sankcjonowanie istniejącej praktyki pomijania formalnego wymogu

36 Zdanie to zostało w oryginale dokumentu podkreślone ciągłą linią (IV g 22 2099/42). 
złożenia wniosku o wpisanie na volkslistę i wystawiania z urzędu wezwania do służby wojskowej, by tak wytworzonego „Volksdeutscha” wysyłać na front. Wszelkie natomiast próby uniknięcia służby traktowano jako zbrodnicze usiłowanie uchylenia się od obowiązku obrony Rzeszy.

Akta sprawy zamyka dokument informujący, że w sprawie skazanego na śmierć Wacława Miszalowkiego: „...nie korzystam $z$ nadanego mi przez Führera prawa łaski, lecz pozostawiam wolny bieg sprawiedliwości. Berlin, 17 grudnia 1942.Minister sprawiedliwości Rzeszy Thierack”. Informację o wykonaniu wyroku szeroko rozplakatowano, co stanowiło formę terroryzowania polskich mieszkańców Pomorza, straszenia ich niemieckim prawem i odwodzenia od podejmowania jakichkolwiek prób uniknięcia służby w niemieckim wojsku ${ }^{37}$.

\section{Proces Alberta Forstera przed Najwyższym Trybunałem Narodowym}

Wezwanie z 22 lutego 1942 r. o wpisywanie się na niemiecką listę narodowościową stało się podstawą systemu wymuszania deklaracji od każdego, kto urodził się na terenie poddanym władzy gauleitera, przy czym szczególną uwagę zwrócić trzeba na to, że w wezwaniu nie wymieniano jako warunku posiadania „krwi niemieckiej”, lecz na pierwszym miejscu wskazywano na każdego, kto „czuje się Niemcem”. W procesie Forstera przed NTN (sesja wyjazdowa w Gdańsku 5-29 kwietnia 1948 r.) oskarżenie ukazało, w jak perfidny sposób wzbudzano owo poczucie przynależności do niemczyzny, mające przejawić się w złożeniu formalnego wniosku. W postępowaniu dowodowym przedstawiony został formularz, który musiał wypełnić każdy, kto ociągałby się z postąpieniem w sposób wskazany w wezwaniu gauleitera, zawierający następujący fragment: „Zwrócono mi uwagę, że mimo niemieckiego pochodzenia i publicznej odezwy nie złożyłem dotąd podania do urzędu niemieckiej volkslisty. $\mathrm{Z}$ polecenia Gestapo oświadczono mi, że w ciągu ośmiu dni mam

37 M. Podgóreczny, op.cit., s. 387-388. 
złożyć podanie o przyjęcie do niemieckiej volkslisty. Pismo to dobrze zrozumiałem. Zwrócono mi również uwagę na to, że w przypadku niezastosowania się do niniejszego mogę oczekiwać policyjnego trybu postępowania”. Skonfrontowani $z$ takim żądaniem, mieli pełną świadomość, co znaczy czekające ich „postępowanie w trybie policyjnym", ponieważ w specjalnym dekrecie Himmler zarządził, że osoby niemieckiego pochodzenia, które nie będą ubiegać się o rejestrację na volksliście, mają zostać objęte aresztem prewencyjnym i wysłane do obozów koncentracyjnych ${ }^{38}$.

W procesie Forstera świadek Franciszek Wierzba opisał postępowanie oskarżonego gauleitera wobec odmawiającego złożenia wniosku o wpisanie na volkslistę artysty malarza Zbigniewa Urbanowskiego, którego kopie dzieł publikowała prasa, podając, że stworzył je „heimatlicher Künstler (rodzimy artysta) Z. Urban”. Gdy w obecności Forstera, który na początku 1944 r. w towarzystwie swej świty odwiedził pracownię Urbanowskiego, artysta po raz kolejny odmówił złożenia deklaracji zniemczenia, ponieważ jako Polak nie chciał zostać niemieckim żołnierzem, oburzony gauleiter miał polecić natychmiastowe posłanie opornego do obozu koncentracyjnego. Po trzydniowym ukrywaniu się, przerażony Urbanowski złożył podpis na volksliście, przyjmując zapewnienie, że nie zostanie powołany do Wehrmachtu, co jednakże nastąpiło po dwóch miesiącach. Po krótkim przeszkoleniu jego jednostka została posłana do Słowacji, a następnie na Węgry, gdzie zginął.

Oskarżony Forster zaprzeczał zarzutom aktu oskarżenia, wywodząc: „Muszę stwierdzić, że ja osobiście występowałem przeciwko stosowaniu jakiegokolwiek przymusu. Muszę wyraźnie i uczciwie stwierdzić, że jeżeli dzisiaj mówi się o przymusie wpisywania na volkslistę, to nie jest to słuszne”. Pytany w czasie rozprawy o jego polecenie odnośnie do Urbanowskiego, powiedział: „Nie sądzę, abym z Urbanowskim mówił w ogóle o sprawach wpisywania się na volkslistę. $\mathrm{W}$ trakcie rozmowy chodziło o sprawy artystyczne... oddzielałem zasadniczo politykę od sztuki..."39. Odnosząc się do

38 C. Epstein, op.cit., s. 209.

39 M. Podgóreczny, op.cit., s. 393. Zob. tamże komentarz prokuratora NTN Mieczysława Siewierskiego przytaczającego odezwę Forstera do ludności Po- 
traktowania Polaków, Forster stwierdził: „W ciągu lat, wbrew moim przełożonym w Berlinie, częstokroć mówiłem i pisałem o usunięciu pewnych ograniczeń i o wprowadzeniu równouprawnienia Polaków z Niemcami”. W protokole rozprawy odnotowano po tych słowach: „Powszechny śmiech na sali”" ${ }^{40}$.

Trybunał uznał oskarżonego za winnego tego, że „na terenie prowincji Gdańsk - Prusy Zachodnie w czasie od 1 września 1939 r. do maja 1945 r., idąc na rękę władzy państwa niemieckiego [...], działał na szkodę Państwa polskiego i jego ludności cywilnej, biorąc udział: [...] 2. w masowym wysiedlaniu tych ludzi do tzw. Generalnej Guberni i obozów przesiedleńców oraz do robót przymusowych w Rzeszy, [...] 4. w wynaradawianiu Polaków przez zmuszanie ich do wpisywania się na niemiecką listę tak w drodze przymusu bezpośredniego, jak i utrudniania warunków bytu tym, którzy nie odstąpili od polskiej narodowości”. Czyny te stanowiły zbrodnię $z$ art. 2 dekretu o wymiarze kary dla faszystowsko-hitlerowskich zbrodniarzy z 31 sierpnia $1944 \mathrm{r}^{41}$

Na zakończenie tej części rozważań poczynić trzeba uwagę, że wymienieni powyżej najwyżsi funkcjonariusze narodowosocjalistycznych Niemiec nie różnili się między sobą, gdy chodzi o finalny cel ich działań, jakim miało być „ostateczne zwycięstwo” nad pokona-

morza z dnia 22 lutego 1942 r.: „Jeśli mam podstawę twierdzić, że ta rozmowa miała taki przebieg, jak ją odtworzył świadek Wierzba, to dlatego, że oskarżony Forster w rozmowie tej nie wykroczył ani o włos poza to, co zapowiedział w tej odezwie".

${ }^{40}$ M. Podgóreczny, op.cit., s. 369. Artur Greiser, gauleiter Kraju Warty, w trakcie procesu przed NTN dzielił się refleksją: „obiektywni badacze historii [...] muszą uznać, że $z$ Polaka nie można zrobić Niemca ani przez germanizację, ani przez nadanie praw obywatelskich”. Twierdził także: „potrzebowałem nie tylko mieszkających tutaj Polaków, ale nawet bardzo usilnie starałbym się o zwrócenie mi również tych, którzy zostali przesiedleni do Generalnego Gubernatorstwa”. W protokole rozprawy zapisano: „Wesołość na sali” (W. Kulesza, Wysiedlenia, s. 47).

${ }^{41}$ Wyrok skazujący Forstera na karę śmierci zawiera opis całego szeregu zbrodni, za które był odpowiedzialny, i wraz z uzasadnieniem liczy 90 stron maszynopisu. Opublikowany w: T. Cyprian, J. Sawicki, Siedem wyroków Najwyższego Trybunału Narodowego, Poznań 1962. 
nymi we wrześniu 1939 r. Polakami, których warstwy przywódcze mordowane były od pierwszych dni wojny. $Z$ historycznej i prawnej perspektywy pozostają zatem bez znaczenia rozbieżności w ich poglądach na to, w jakim zakresie i w jaki sposób wykorzystać pozostających przy życiu Polaków - czy jako przymusowo, formalnie zgermanizowanych żołnierzy Wehrmachtu, pod groźbą karania prowadzącego do śmierci za jakikolwiek przejaw nieposłuszeństwa wobec wezwania do służby, czy jako tanią siłę roboczą w podbitym kraju, czy jako niewolniczą siłę roboczą w „starej Rzeszy”, czy też więźniów obozów koncentracyjnych ${ }^{42}$. To, co należy podkreślić jako charakterystyczne dla nich wszystkich, sprawujących swą nieograniczoną władzę na terenie okupowanej Polski, to negowanie później przez każdego $z$ nich swej własnej odpowiedzialności za realizację narodowosocjalistycznego bezprawia.

Albert Forster, stojąc przed polskim Trybunałem, twierdził, że to „Hitler ponosi winę za upadek naszego państwa”43. Podkreślał, że Himmler nie spełnił jego oczekiwań i nie uczynił go swym pełnomocnikiem do spraw umacniania niemczyzny w okręgu Gdańsk Prusy Zachodnie ${ }^{44}$. Twierdził: „Oświadczam, że to Himmler był komisarzem Rzeszy dla umocnienia niemczyzny i w tych sprawach rozkazywał, i on był za to odpowiedzialny"45. Wywodził w procesie w swym ostatnim słowie: „Jeśli uczyniłem coś złego, to tylko w związku $\mathrm{z}$ narzuconą mi polityką, w związku $\mathrm{z}$ zajmowanym przeze mnie stanowiskiem i na skutek zdarzeń i wydarzeń, które nie były wywołane przeze mnie" 46 .

Richard Hildebrandt, wyższy dowódca SS i policji, którego Himmler mianował swym przedstawicielem dla umacniania niemczyzny w okręgu Gdańsk - Prusy Zachodnie, mówił o swym zwierzchniku: „Ten człowiek, którego co drugie, trzecie słowo to było "wierność",

${ }^{42}$ Różnice w poglądach Himmlera, Forstera i Greisera przedstawia szczegółowo C. Epstein, op.cit., s. 207 i n.

${ }^{43}$ D. Schenk, op.cit., s. 401.

${ }^{44}$ M. Podgóreczny, op.cit., s. 370.

${ }^{45}$ Ibidem, s. 372.

${ }^{46}$ Ibidem, s. 422. 
uchylił się od odpowiedzialności przez tchórzliwe samobójstwo w 1945 r. To Himmler jest winien, że stoję przed sądem..."47. Greiser, który był pełnomocnikiem dla umacniania niemczyzny w rządzonym przezeń Kraju Warty, tłumaczył się przed polskim Trybunałem następująco: „Otrzymałem nakaz od Hitlera, by zniemczyć kraj [Polskę]. Mogę potwierdzić, że Himmler miał bzika rasowego. Dowodzi tego przede wszystkim jego decyzja o przesunięciu tzw. granicy narodowej niemieckiej na wschód"48.

Generalny Gubernator Hans Frank zwierzał się w Norymberdze: „Rozsądek zaczął mi wracać w 1942 r. i zdałem sobie sprawę, jakie zło się w nim [Hitlerze] ucieleśniało. Było w nim szatańskie zło [...] zwąchał się z szatanem. W latach późniejszych uświadomiłem sobie, jak bezwzględnym, ciężkim i bezdusznym był psychopatą. Oto dlaczego ufał tylko takim "działaczom" jak Himmler i Bormann" 49 .

Prokurator generalny Fritz Bauer ${ }^{50}$, który doprowadził do procesu członków załogi Auschwitz przeprowadzonego we Frankfurcie nad Menem (1963-1965), skomentował powszechną postawę przyjętą przez Niemców w kwestii odpowiedzialności za zbrodnie nazistowskie: „Nie było w Niemczech tak, że był tylko nazista Hitler i tylko nazista Himmler. Były setki tysięcy, miliony innych, którzy przeprowadzili to, co się wydarzyło, nie tylko dlatego, że tak im rozkazano, lecz także dlatego, że taki był ich własny światopogląd, który przyjęli dobrowolnie" ${ }^{51}$. Stwierdzenie to odnieść trzeba także do niemieckich prawników, w tym do sędziów Sondergerichtu w Toruniu i Reichsgerichtu w Berlinie.

${ }^{47}$ W. Kulesza, Völkermord vor Gericht in Polen. NS-Verbrechen im Reichsgau Danzig-Westpreußen im Lichte des Strafprozesses gegen Richard Hildebrandt, w: Kriegsverbrechen, NS-Gewaltverbrechen und die europäische Strafjustiz von Nürnberg bis Den Haag, Hrsg. H. Halbrainer, C. Kuretsidis-Haider, Graz 2007, s. 204.

${ }^{48}$ W. Kulesza, Wysiedlenia, s. 43; F. Bauer, Die Humanität der Rechtsordnung. Ausgewählte Schriften, Frankfurt/Main 1998.

${ }^{49}$ G.M. Gilbert, Dziennik norymberski, przeł. T. Łuczak, Warszawa 2012, s. 31 .

${ }^{50}$ W. Kulesza, Przedmowa do polskiego wydania, w: Auschwitz przed sądem. Proces we Frankfurcie nad Menem 1963-1965. Dokumentacja, red. H. Langbein, Wrocław-Warszawa-Oświęcim 2011, s. XVIII.

${ }^{51}$ F. Bauer, Die Humanität, s. 110. 


\section{Sytuacja wpisanych na volkslistę po wojnie}

Rozporządzenie $z$ dnia 1 sierpnia 1944 r. Krajowej Rady Ministrów o utracie obywatelstwa przez Niemców ${ }^{52}$ stanowiło, że za Niemca uważany jest także ten, kto po 1 września 1939 r. został wpisany na niemiecką listę narodową lub uznany został za obywatela niemieckiego (art. 3). Kolejny przepis głosił: „Niemcy mają obowiązek opuścić obszar Państwa Polskiego. Minister Spraw Wewnętrznych ustali terminy i sposób wykonania tego obowiązku”. Rozporządzenie tego samego organu wydane $z$ tą samą datą, o Polakach zaliczonych w czasie okupacji do Niemców ${ }^{53}$, deklarowało, że „Obywatel polski narodowości polskiej, który w okresie okupacji otrzymał obywatelstwo Rzeszy Niemieckiej lub został wpisany na niemiecką listę narodową [...] choćby na podstawie swego wniosku, nie będzie podlegał przepisom dotyczącym Niemców, o ile wykaże, że przed 1 września 1939 r. dawał wyraz swej przynależności do narodu polskiego, a w czasie wojny i okupacji faktycznie nie zerwał z polskością” (art. 1). Następnie określony został tryb postępowania administracyjnego, który rozpoczynał się od złożenia w zarządzie gminy miejsca zamieszkania „deklaracji polskości z wnioskiem o uznanie deklaranta za Polaka” (art. 2, art. 3). Temu, „kto w deklaracji polskości złożył fałszywe oświadczenie”, groziła kara więzienia do lat 5 (art. 13).

Kodeks karny Wojska Polskiego z 23 września 1944 r. w art. 100 stanowił, że ten, kto będąc obywatelem polskim, „dobrowolnie zgłasza lub zgłosił w czasie wojny swą przynależność do obcej narodowości, walczącej z Państwem Polskim, podlega karze więzienia na czas nie krótszy od lat 5”. Kodeks karny z 1932 r. groził karą więzienia na czas nie krótszy niż lat 10 każdemu, kto, „będąc obywatelem polskim, przyjmuje obowiązki w wojsku nieprzyjacielskim”. A jeżeli „sprawca bierze udział w działaniach wojennych przeciw Państwu Polskiemu, podlega karze więzienia dożywotnio albo karze śmierci”.

\footnotetext{
${ }^{52}$ Dz.U. z 1944 r., Część III, Nr 2, poz. 7.

${ }^{53}$ Dz.U. z 1944 r., Część III, Nr 2, poz. 8.
} 
Wydany 4 listopada 1944 r. dekret o środkach zabezpieczających w stosunku do zdrajców Narodu odnosił się do Polaków, którzy w czasie wojny znajdowali się w Generalnym Gubernatorstwie ${ }^{54}$.

Dekret Krajowej Rady Narodowej z 28 lutego 1945 r. o wyłączeniu ze społeczeństwa polskiego wrogich elementów ${ }^{55}$ uwzględniał warunki, w jakich znaleźli się Polacy na ternach włączonych do Rzeszy (Gdańsk - Prusy Zachodnie, Kraj Warty), stanowiąc: „Obywatele Państwa Polskiego wpisani po dniu 31 sierpnia 1939 r. na obszarach Rzeczypospolitej Polskiej, wcielonych przemocą przez okupanta do Rzeszy Niemieckiej, oraz na obszarze byłego Wolnego Miasta Gdańska do trzeciej lub czwartej grupy niemieckiej listy narodowej (Deutsche Volksliste) [...] posiadają pełnię praw obywatelskich, jeżeli wciągnięci zostali na tę listę wbrew swojej woli lub pod przymusem, a swoim zachowaniem się wykazali polską odrębność narodową" (art. 1). Wymagano równocześnie, by obywatele wskazani w tym przepisie, którzy ukończyli 14 lat, złożyli właściwej władzy administracyjnej (starostom) „deklarację wierności Narodowi i Demokratycznemu Państwu Polskiemu" (art. 2 ust. 1), co otwierało drogę do uzyskania odpowiedniego zaświadczenia. Postanowienia dekretu zostały powtórzone przez Ustawę z 6 maja 1945 r. o wyłączeniu ze społeczeństwa polskiego wrogich elementów ${ }^{56}$, która przewidywała wydawanie przez właściwych miejscowo starostów stosownych zaświadczeń osobom przymusowo wpisanym w części III i IV niemieckiej listy narodowościowej, po złożeniu przez nich we właściwym dla miejsca zamieszkania starostwie deklaracji wierności (art. 2 ust. 1) ${ }^{57}$. Ustawa

${ }^{54}$ Dekret ten stanowił: „Art. 1. Obywatel polski, który w okresie okupacji niemieckiej na terytorium t.zw. Generalgouvernement i województwa białostockiego bądź zadeklarował swoją przynależność do narodowości niemieckiej (deutsche Volkszugehörige) lub swoje pochodzenie niemieckie (deutschstämmige) bądź faktycznie korzystał z praw i przywilejów z tytułu przynależności do narodowości niemieckiej lub pochodzenia niemieckiego, podlega, niezależnie od odpowiedzialności karnej, przytrzymaniu, umieszczeniu na czas nieoznaczony w miejscu odosobnienia (obozie) i poddaniu przymusowej pracy”. Dz.U. z 1944 r., Nr. 11, poz. 54.

55 Dz.U. z 1945 r. Nr 7, poz. 30.

${ }^{56}$ Dz.U. z 1945 r. Nr 17, poz. 96.

57 Formularz deklaracji zawierał następujący fragment: „oświadczam, że zostałem(am) wpisany(a) przez niemieckie władze okupacyjne do trzeciej (czwartej) 
określała, że „na obszarach, na których nie był stosowany przymus przez okupanta przy wciąganiu na niemiecką listę narodową, osoby powinny, oprócz zgłoszenia deklaracji wierności, wykazać, że zostały wbrew swojej woli lub pod przymusem wpisane na niemiecką listę narodową" (art. 8 ust. 1). Wnioski o rehabilitację rozpatrywały sądy grodzkie, zarządzające na koszt wnioskodawców ogłoszenie o wszczęciu postępowania, także przez zamieszczenie „w jednym lub więcej pismach periodycznych" (art. 13 ust. 1) ${ }^{58}$. W razie odrzucenia wniosku o rehabilitację sąd grodzki wydawał postanowienie: „umieszczenie wnioskodawcy na czas nieoznaczony w miejscu odosobnienia (obozie), poddanie go przymusowej pracy, utratę na zawsze praw publicznych [...] tudzież przepadek całego mienia”.

Według oficjalnego wykazu zaludnieniu więzień i obozów Ministerstwa Bezpieczeństwa Publicznego na początku października 1945 r. przebywało w nich 29195 osób w rubryce „rodzaj przestępców” określonych jako Volksdeutsch, z końcem 1947 r. były to 33463 osoby negatywnie zweryfikowane, a także osadzone na polecenie Urzędu Bezpieczeństwa bez przeprowadzenia postępowania ${ }^{59}$.

Odnoszący się do całego obszaru Polski dekret z 28.06.1946 r. o odpowiedzialności karnej za odstępstwo od narodowości w czasie wojny 1939-1945 r. ${ }^{60}$ przewidywał na wstępie: „Kto, będąc obywatelem polskim, w czasie pomiędzy 1 września 1939 r. a 9 maja

grupy niemieckiej listy narodowej (do grupy t. zw. Leitungs-Pole) wbrew swej woli (pod przymusem) - niepotrzebne skreślić. Pomny(a) swej polskiej przynależności narodowej, przyrzekam uroczyście dochować wierności Narodowi i demokratycznemu Państwu Polskiemu oraz sumiennie wypełniać moje obowiązki obywatelskie”. Załącznik Nr 1 do rozporządzenia Ministra Administracji Publicznej z dnia 25 maja 1945 r. w sprawie rehabilitacji osób wpisanych do trzeciej i czwartej grupy niemieckiej listy narodowej lub do grupy t. zw. Leistungs-Pole, Dz.U. z 1945 r. Nr 21, poz. 128.

58 Niemcy $w$ Polsce 1945-1950. Wybór dokumentów, red. W. Borodziej, H. Lemberg, T. I, Warszawa 2000, s. 48.

59 Ibidem, s. 174, 255. Zob. także: W. Kulesza, Polska godność narodowa $w$ świetle prawa karnego, „Czasopismo Prawno-Historyczne” 2018, t. LXX, z. 1 , s. 172 .

60 Dz.U. z 1946 r. Nr 41, poz. 237. O obozach zob. B. Kopka, Niemcy i Polacy $w$ obozach pracy administrowanych przez resort bezpieczeństwa publicznego $w$ Polsce 1945-1954: terror i praca, w: Władze komunistyczne wobec ludności 
1945 r. zgłosił swoją przynależność do narodowości niemieckiej [...], podlega karze więzienia do 10 lat (art. $1 \S 1$ )”. Podstawy wyłączenia karalności określone zostały w art. 4 który stanowił: „Nie podlega karze: a) kto zgłosił swoją przynależność do narodowości niemieckiej [...] w celu uniknięcia ciężkiego prześladowania ze strony władz albo organizacji politycznych niemieckich za trwanie przy swojej narodowości, jeżeli prześladowania nie można było bez szczególnych trudności uniknąć w inny sposób”. W końcowej części przepis deklarował, że „nie podlega karze, kto również przed 1 września 1939 r. stale wykazywał swoją przynależność do narodowości niemieckiej” (art. 4. a). Współcześni badacze zauważają, iż powoływanie się przez skonfrontowanych $z$ zarzutem odstępstwa od polskiej narodowości, że już przed wybuchem wojny przynależeli oni do niemczyzny, stało się aż do 1950 r. (ustawa amnestyjna), dość powszechnie stosowanym sposobem uniknięcia odpowiedzialności karnej za odstępstwo od narodowości polskiej w czasie wojny ${ }^{61}$. Trudno inaczej określić ten stan rzeczy, aniżeli jako swoisty paradoks prawno-historyczny.

\section{STRESZCZENIE}

Polacy wpisani na volkslistę a obowiązek służby w Wehrmachcie w świetle wyroków Sądu Specjalnego w Toruniu

Polacy, którzy zamieszkiwali w północnej części pokonanej we wrześniu 1939 r. Polski, byli przez niemieckie władze przymusowo poddawani germanizacji poprzez wpisywanie ich na niemiecką listę narodowościową i wbrew swej woli wcielani do niemieckiego wojska. Jakiekolwiek próby uniknięcia powołania do Wehrmachtu także przez tych, którzy nie mieli obywatelstwa III Rzeszy, były karane jako usiłowanie popełnienia zbrodni osłabiania mocy

niemieckiej $w$ Polsce $w$ latach 1945-1989, red. A. Dziurok, P. Malajczyk, S. Rosenbaum, Warszawa 2016, s. 476 i n.

${ }^{61}$ J. Kochanowski, Losy Niemców $w$ Polsce Centralnej $w$ latach 1945-1950, w: Niemcy $w$ Polsce 194 -1950. Wybór dokumentów, red. W. Borodziej, H. Lemberg, T. II, Warszawa 2000 , s. 48 przypis 127 . W opracowaniu tym przedstawiona została szczegółowo kwestia Volksdeutsche jako problem prawny (s. 43 i n.). 
obronnej niemieckiego państwa. W okrutnym karaniu opornych Polaków miał swój udział niemiecki Sąd Specjalny w Toruniu, który wezwanego do służby wojskowej Polaka skazał m.in. na karę śmierci za to, że ten, nie chcąc opuścić swej niemieckiej żony, obciął sobie palce jednej ręki. Sąd Najwyższy Rzeszy sformułował zasadę, że Polacy, którzy otrzymają powołanie do wojska, choćby nie mieli niemieckiego obywatelstwa, mają być karani. Polacy wezwani do służby w Wehrmachcie znaleźli się w sytuacji bez wyjścia. Mogli zginąć na froncie albo w niemieckim więzieniu lub obozie koncentracyjnym. Dlatego ci, którzy zostali przymusowo wcieleni do Wehrmachtu, często dezerterowali, za co także groziła im kara śmierci.

Słowa kluczowe: Torun w okresie II wojny światowej; Polacy w Wehrmachcie; niemiecka lista narodowościowa; Volksdeutsche; niemiecki Sąd Specjalny w Toruniu

\section{SUMMARY}

Poles inscribed on the Volkslist and duty to serve in the Wehrmacht in the light of the verdicts of the Special Court in Torun

Poles who lived in the northern part of Poland defeated in September 1939, were forcibly subjected to germanization by the German authorities enrolling them onto a list of German nationals (Volksliste) and incorporating into the German army against their will. Any attempts to avoid the appointment to the Wehrmacht, also by those who did not have the citizenship of the Third Reich, were punished as attempts to commit the crime of weakening the defense power of the German state. The cruel punishment of resistant Poles was performed by a German Special Court in Torun, which sentenced, among others, to a death penalty a Pole who was called to military service, but while not wanting to leave his German wife, he cut off his fingers to avoid the enrollment. The Supreme Court of the Reich established the principle that Poles who receive a military appointment, even if they did not have German citizenship, are to be punished. The Poles called to serve in the Wehrmacht found themselves in an impossible situation. They could have died at the front or in a German prison or a concentration camp. Therefore, those who were forcibly incorporated into the Wehrmacht often deserted, for which they were also threatened with the death penalty. 
Keywords: Torun during World War II; Poles in the Wehrmacht; German national list; Volksdeutsch; German Special Court in Toruń

\section{BIBLIOGRAFIA}

Bauer F., Die Humanität der Rechtsordnung. Ausgewählte Schriften, Frankfurt/Main 1998.

Borodziej W., Lemberg H. (red.), Niemcy w Polsce 1945-1950. Wybór dokumentów, T. I, Warszawa 2000.

Cyprian T., Sawicki J., Siedem wyroków Najwyższego Trybunału Narodowego, Poznań 1962.

Dalcke A., Strafrecht und Strafverfahren, Berlin-München 1940.

Dunin-Wąsowicz K., Obóz koncentracyjny Stutthof, Gdańsk 1970.

Epstein C., Wzorcowy nazista. Arthur Greiser i okupacja Kraju Warty, przeł. J. Włodarczyk, Wrocław 2010.

Gilbert G.M., Dziennik norymberski, przeł. T. Łuczak, Warszawa 2012.

Kochanowski J., Losy Niemców w Polsce Centralnej w latach 1945-1950, w: Niemcy $w$ Polsce 1945-950. Wybór dokumentów, red. W. Borodziej, H. Lemberg, T. II, Warszawa 2000.

Kopka B., Niemcy i Polacy $w$ obozach pracy administrowanych przez resort bezpieczeństwa publicznego w Polsce 1945-1954: terror i praca, w: Wtadze komunistyczne wobec ludności niemieckiej $w$ Polsce $w$ latach 1945-1989, red. A. Dziurok, P. Malajczyk, S. Rosenbaum, Warszawa 2016.

Kulesza W., Crimen laesae iustitiae. Odpowiedzialność karna sędziów i prokuratorów za zbrodnie sądowe według prawa norymberskiego, niemieckiego, austriackiego i polskiego, Łódź 2013.

Kulesza W., Polska godność narodowa $w$ świetle prawa karnego, „Czasopismo Prawno-Historyczne" 2018, t. LXX, z. 1.

Kulesza W., Przedmowa do polskiego wydania, w: H. Langbein, Auschwitz przed sadem. Proces we Frankfurcie nad Menem 1963-1965. Dokumentacja, Wrocław-Warszawa-Oświęcim 2011.

Kulesza W., Sąd Specjalny (Sondergericht) w Łodzi, w: Gmach i jego tajemnice. Sąd Okręgowy w Łodzi 1917-2017, Łódź 2017.

Kulesza W., Völkermord vor Gericht in Polen. NS-Verbrechen im Reichsgau Danzig-Westpreußen im Lichte des Strafprozesses gegen Richard Hildebrandt, w: Kriegsverbrechen, NS-Gewaltverbrechen und die europäische Strafjustiz von Nürnberg bis Den Haag, Hrsg. H. Halbrainer, C. Kuretsidis-Haider, Graz 2007.

Kulesza W., Wysiedlenia z Kraju Warty (Warthegau) $w$ świetle procesu Gauleitera Artura Greisera, w: Ludność cywilna w Łódzkich obozach przesiedleńczych, red. J. Żelazko, Łódź 2010. 
Podgóreczny M., Albert Forster. Gauleiter i oskarżony, Gdańsk 1977.

Proces Artura Greisera przed Najwyższym Trybunałem Narodowym, Główna Komisja Badania Zbrodni Niemieckich w Polsce, Warszawa 1946.

Przybyszewski K., Z działalności hitlerowskiego Sądu Specjalnego (Sondergericht) $w$ Toruniu 1942-1943, „Rocznik Toruński”, T. 2, Toruń 1967.

Ritter E., Justiz und innere Verwaltung, w: Enzyklopädie des Nationalsozialismus, München 1998.

Sagenschneider M., 50 Klassiker Prozesse, Hildesheim 2005.

Schenk D., Albert Forster gdański namiestnik Hitlera, przeł. W. Tycner, J. Tycner, Gdańsk 2002.

Schlüter H., „... für die Menschlichkeit im Strafmaß bekannt...”. Das Sondergericht Litzmannstadt und sein Vorsitzender Richter, „Juristische Zeitgeschichte NRW“, Band 14, Recklinghausen 2007.

Wardzyńska M., Wysiedlenia z okupowanych ziem polskich włączonych do III Rzeszy $w$ latach 1939-1945, Warszawa 2017.

Waszczyński J., Z działalności hitlerowskiego Sądu Specjalnego $w$ Łodzi $w$ Łodzi (1939-1945), „Biuletyn Głównej Komisji Badania Zbrodni Hitlerowskich w Polsce" 1972, t. XXIV. 
